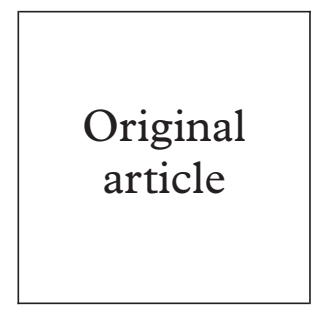

The University of Alabama at Birmingham, School of Public Health, Department of Epidemiology and International Health, Birmingham, Alabama, USA L Gibney M Macaluso K Kirk

S H Vermund

BIRDEM (Bangladesh Institute of Research \& Rehabilitation in Diabetes, Endocrine and Metabolic Disorders), Dhaka, Bangladesh M S Hassan

The University of Alabama at Birmingham, Division of Infectious Diseases, Birmingham, Alabama, USA J Schwebke

Paricharja (a non-profit, non-governmental organisation), Dhaka, Bangladesh P Choudhury

Correspondence to: Dr Laura Gibney, The University of Alabama at Birmingham, 217G Ryals Building, 1665 University Boulevard, Birmingham, AL 35294-0022, USA lgibney@uab.edu

Accepted for publication 22 May 2001

\title{
Prevalence of infectious diseases in Bangladeshi women living adjacent to a truck stand: HIV/STD/hepatitis/genital tract infections
}

\author{
Laura Gibney, Maurizio Macaluso, Katharine Kirk, M S Hassan, Jane Schwebke, \\ Sten H Vermund, Parwez Choudhury
}

Background: Little is known about infection rates for human immunodeficiency virus (HIV) and other diseases that can be transmitted sexually in Bangladeshi women who may be at intermediate levels of risk - that is, women who are not commercial sex workers (CSWs) but whose sexual contacts may include men at high risk for STD. This study examines HIV/hepatitis/STD and other genital tract infections in women living near Tejgaon truck stand in Dhaka, Bangladesh. Methods: This population based study was conducted from January to December 1998. A random sample of 384 women provided urine and blood samples and participated in an interview; 261 of them also had a physical examination in which vaginal and cervical specimens were taken. Laboratory tests included PCR on urine and cervical swabs for gonorrhoea and chlamydia, culture for trichomoniasis, serology tests for syphilis, herpes simplex 2, hepatitis B, C, D, HIV1, HIV2, and clinical diagnoses of other genital tract infections.

Results: None of the participants tested positive for HIV. In the 261 women who had a physical examination, trichomoniasis was detected in $19.5 \%$, chlamydia in $3.4 \%$, gonorrhoea in $5.4 \%$, bacterial vaginosis in $37.2 \%$, and candidiasis in $10 \%$. In the full sample of 384 women, with tests of urine and blood, prevalence of infection with chlamydia, gonorrhoea, syphilis, and herpes simplex 2 was detected in $0 \%, 6.3 \%, 5.7 \%$, and 32\% respectively. Almost $50 \%$ of the subjects had ever been exposed to hepatitis B, 3.6\% were currently infective, $1.6 \%$ had hepatitis $\mathrm{C}$, and none had hepatitis D.

Conclusion: The high prevalence of certain of these infectious diseases indicates the need to implement prevention interventions with these women and, perhaps more importantly, with their male partners. Qualitative research is needed to provide insights into their sexual behaviour and the contexts in which high risk behaviours occur.

(Sex Transm Inf 2001;77:344-350)

Keywords: sexually transmitted diseases; Bangladesh; truck drivers

\section{Introduction}

Bangladesh has had few published population based studies of diseases that can be transmitted sexually (HIV, STD, hepatitis) or of non-sexually transmitted genital tract infections. Data suggest that the country has low rates of HIV infection in general, and in women specifically. Out of 102 cumulative cases reported to the National AIDS Committee by December 1998, only 18 cases were women (N Islam, personal communication, 1999). Sexually transmitted diseases (STD) are also uncommon among women in the general population $^{1}$ though rates are high among commercial sex workers (CSW). ${ }^{2-4}$ Previous research suggests that Bangladesh has an intermediate prevalence of hepatitis $\mathrm{B}$ infection, with the highest recorded rates of HBsAg being in professional blood donors and CSW. ${ }^{5-10}$ There are only two published studies of hepatitis $\mathrm{C}$; one reported a prevalence of $2.4 \%$ in professional donors and $0 \%$ in voluntary donors $^{10}$ and another $56 \%$ in patients with hepatocellular carcinoma. ${ }^{11}$

Little is known about infection rates in Bangladeshi women who may be at intermediate levels of risk for these diseases-that is, women who are not CSWs but are likely to be at higher risk than women in the general population because of their contacts with men at high risk for STD, such as truck drivers, workers returning from abroad, and injecting drug users. This study focuses on one such group of women living in a slum encircling Tejgaon truck stand, one of the largest truck stands in Dhaka. Although there were only two cases of HIV infection in Bangladeshi truck drivers reported to the National AIDS Committee by December 1998 (Nazrul Islam, personal communication, 1999) and sentinel surveillance found zero prevalence in truck drivers in $1999,{ }^{4}$ truck drivers have been identified as important to the transmission of HIV infection elsewhere. In sub-Saharan Africa rates of HIV infection in truck drivers as high as $26-35 \%$ have been reported. ${ }^{12-15}$ Studies of truck drivers in subSaharan Africa, Thailand, and India have also reported high levels of unsafe sexual activity such as sex with CSWs, frequent change of sexual partners, and multiple partners. ${ }^{14}{ }^{16-18} \mathrm{~A}$ study of 388 truck drivers and truck helpers in Tejgaon found high levels of unsafe sexual activity; 211 of the men (54\%) acknowledged having sex with one or more female CSWs in the past year and condom use was rare even in sexual encounters with CSWs (Gibney et al, unpublished data, 2000). Two studies found 
Key messages

- HIV was clearly not a problem in this population $(n=384)$ as not a single case of infection was found.

- There was, however, a high prevalence of classic STD: HSV-2 (32\%), syphilis $(5.7 \%)$, and gonorrhoea $(6.3 \%)$. In a subsample (n $=261$ ) that had a physical examination, trichomoniasis was detected in $19.5 \%$.

- Although almost $50 \%$ had ever been exposed to hepatitis B only $3.6 \%$ were currently infective, $1.6 \%$ had hepatitis $\mathrm{C}$, and none had hepatitis D.

- When the findings of our study are compared with (i) a study of rural women and a study of urban slum women, and (ii) with studies of CSWs in Bangladesh, it appears that women living near the truck stand are at an intermediate level of risk (that is, at higher risk than women in the general population but at lower risk than CSWs). However, comparisons between these studies must be made cautiously as different tests or different testing procedures were sometimes used.

- Given the very low levels of condom use in Bangladesh, it is unlikely that efforts to promote condom use to these women for sexual relations with their primary partner would be successful. Promoting condom use by their primary partners in the context of their casual sexual relations, particularly with CSWs, would be an important prevention strategy.

truck drivers to be an important client group for CSWs in Bangladesh. ${ }^{19} 20$

Women living in close proximity to truck stands are likely to be at higher risk for $\mathrm{STD} / \mathrm{HIV}$, given that some of the women will engage in sexual relations with men in the trucking industry and others will have male partners who are sexually active with the same women (particularly CSWs) as the truck drivers. A study in Kenya found that $46 \%$ of the adolescent girls living next to a truck stand had sex with truck drivers and $78 \%$ of them received money or a gift in exchange. ${ }^{21}$ In a Tanzanian survey, $50 \%$ of the women living in and around seven truck stands were infected with HIV, and syphilis, gonorrhoea, and chlamydia prevalence was $24 \%, 12 \%$, and $30 \%$ respectively. ${ }^{22}$

This study is the first to characterise the prevalence of HIV, STD (gonorrhoea, chlamydia, syphilis, trichomoniasis, HSV-2) and hepatropic infections (hepatitis B, C, and D), as well as genital tract infections not attributable to STD (bacterial vaginosis, candidiasis), in a population of women living adjacent to a truck stand in Bangladesh. Indeed, it is, to our knowledge, the first such study among Bangladeshi women perceived to be at intermediate levels of risk. The study does not assess behavioural risk factors because of the difficulty we faced in getting women in this culture to discuss sexuality openly in a survey, particularly in the context of extramarital or premarital relations. Further, the greatest risk for STD faced by many of the women living near the truck stand is likely not to be their own behaviour but their primary partner's sexual practices outside their union.

Assessing the prevalence of these diseases is important given their potentially adverse public health consequences. HIV infection would result in a terminal illness for almost all infected Bangladeshis because of the expense, and hence inaccessibility, of the antiretroviral drugs used for treatment in the West. Hepatitis $B$ virus (HBV) and hepatitis $C$ virus (HCV) can lead to serious health consequences such as liver cirrhosis and hepatocellular carcinoma. ${ }^{23-25}$ And co-infections of $\mathrm{HBV}$ and hepatitis delta virus (HDV) cause severe liver disease in many co-infected patients. ${ }^{26}{ }^{27}$ Further, gathering data on hepatitis infections is not only informative about the spread of these diseases but may also provide biological markers of high risk behaviour for future HIV infections (should an epidemic occur in Bangladesh at some point), as injecting drug use, blood transfusions, and needle stick injury are common modes of transmission of both hepatropic and HIV viruses. ${ }^{28}{ }^{29}$ Unprotected sexual intercourse is also a known risk factor for both HIV and HBV and may be a risk factor for HCV infection. ${ }^{30-33}$ Given that hepatitis $\mathrm{B}$ can also be transmitted through other types of casual contacts, ${ }^{34} 35$ it may be less useful than hepatitis C as a marker of high risk injection or transfusion practices.

Both STD (syphilis, trichomoniasis, gonorrhoea, and chlamydia) and genital tract infections not attributable to STD (bacterial vaginosis, candidiasis), can have serious sequelae detrimental to the health of women and infants. Bacterial vaginosis and trichomoniasis can lead to premature rupture of membranes in pregnancy, low birth weight, and pelvic inflammatory diseases (PID). ${ }^{36-38}$ Gonorrhoea and chlamydia may also cause PID, which can lead to infertility, ectopic pregnancy, and chronic pelvic pain. ${ }^{39-43}$ Further, research indicates that both ulcerative STD (syphilis, herpes, chancroid) and non-ulcerative inflammatory infections (gonorrhoea, chlamydia, trichmoniasis, bacterial vaginosis) can be co-factors for HIV infection. ${ }^{44-46}$ Understanding the prevalence of these diseases both in the general population, and in segments of the population at higher risk, is important to inform public health policymaking and programme planning in Bangladesh.

\section{Methods}

STUDY PARTICIPANTS AND PROCEDURES

Between January and December 1998, a cross sectional population based study was conducted at Tejgaon truck stand in Dhaka. The study was approved by the institutional review board of the University of Alabama at Birmingham and the ethics committee of the Bangladesh Medical Research Council.

The study group comprised 384 women aged 15-54 living in a slum encircling Tejgaon truck stand in 1998. Given the large area covered by this slum, and considerations of feasibility of study implementation, a more specific territory with a $1 \mathrm{~km}$ radius around the truck stand was selected.

Household visits were made by research assistants to all households in that area to ascertain if there was at least one woman aged 15-54 living there for at least the past 6 months; all such households were included in the census. The results of the census showed that 1742 women of eligible age range lived in 
the study area. Three female Bangladeshi research assistants visited the homes of 500 women randomly selected from our census list to explain the study and request subjects' participation.

As the expected prevalence of the different diseases varies, the required sample size to detect the true prevalence of disease also varies. For an STD with a relatively low observed frequency of $3 \%$ in a sample of 384 women, the estimate of true prevalence would have $95 \%$ CI of $1.3 \%-4.7 \%$. Assuming a non-participation rate of at least $25 \%$, the number of women selected was increased to 500 from the 384 needed. Of these 500 women, 395 (79\%) agreed to participate and came to the clinic; 11 were later excluded for not giving blood or urine samples.

When a subject consented to participate in the study the field worker returned to the house the next morning to collect a first void urine sample from her. The subject then either came to Paricharja clinic (a non-profit clinic at the truck stand) at that time, accompanied by the field worker, or was requested to come within the next 3 days on her own (the clinic was less than $1 \mathrm{~km}$ walking distance from all subjects' homes). In the clinic, a female research assistant asked subjects questions about their background characteristics using a standardised questionnaire and gave pretest counselling. This was followed by the collection of a blood sample.

For 261 of the 384 subjects, a standard comprehensive physical examination was then conducted by a female physician (99 subjects did not consent to a pelvic examination and 24 were excluded because they were pregnant). Hence, the sample size for the assessment of genital tract infections that required a physical examination with vaginal and cervical specimens taken was $70 \%$ of the study's 384 subjects. Their examination included a pelvic examination with both a speculum and a bimanual exploration. During the speculum examination, the clinician noted the presence and colour of any discharge, as well as any inflammation causing increased redness of the cervix, mucopus, and/or bleeding (for friability). Vaginal and cervical specimens were collected during the pelvic examination for a laboratory investigation to confirm the diagnosis of genital tract infections. Later, a bimanual examination was conducted, and both cervical motion tenderness and adnexal tenderness were noted.

To provide immediate diagnoses and treatment to patients, on-site laboratory tests were performed in the clinic: wet mount for trichomonads, Amsel criteria ${ }^{47}$ for BV, and Gram staining for gonorrhoea. To ascertain prevalence of disease in this population, all other tests were conducted in the Bangladesh Institute of Research and Rehabilitation on Diabetes, Endocrinology and Metabolic Disorder (BIRDEM) laboratory.

Those women who were found to be infected with STD diagnosed at the clinic were given free treatment; women who were pregnant (as determined clinically or by a pregnancy test) were given treatment appropriate to their pregnancy status.

LABORATORY AND CLINICAL TESTS

Laboratory tests were performed in the laboratory of BIRDEM. For quality control, $10 \%$ of all blood and urine samples were sent to the University of Alabama at Birmingham or the ICDDR,B Centre for Health and Population Research in Dhaka to be retested.

Specimens were transported to BIRDEM's laboratory from the field office every day within 2-4 hours of collection. The urine samples were stored at $-70^{\circ} \mathrm{C}$ until the time of analysis. Following crude DNA extraction from the urine, polymerase chain reaction (PCR) was performed using international reagents (Difco, USA). For gonorrhoea and chlamydia, two cervical samples were also collected with swab sticks. The first sample, collected with a Dacron swab was placed in a small plastic tube containing phosphate buffered saline (PBS) media (Sigma, St Louis, MO, USA) and was stored at $-70^{\circ} \mathrm{C}$ until the time of analysis. In the BIRDEM laboratory, crude DNA was extracted from cervical specimens and inhouse PCR was performed using international reagents (Difco, MI, USA). For quality control, 40 samples for the detection of gonorrhoea and chlamydia using PCR were taken to ICDDR,B Centre for Health and Population Research (Dhaka, Bangladesh) and 20 slides for detection of bacterial vaginosis were brought to the University of Alabama at Birmingham for retesting. PCR analysis was conducted on both swabs and urine samples. PCR on swabs was done as it is the more sensitive test, though cervical swabs could only be taken from a subsample of our study group. PCR on urine was done as it could be conducted on the full sample of 384 subjects.

To provide an on-site diagnosis of gonorrhoea, a second cervical sample was collected. A direct Gram smear was performed immediately after the collection of the specimen by rolling the swab over a slide and Gram staining it. The slide was viewed under oil immersion lens $(1000 \times)$; the presence of intracellular Gram negative diplococci in polymorphonuclear leucocytes was considered suggestive of gonorrhoea.

Serology tests for syphilis were performed using rapid plasma reagin (RPR) with a dilution of $1: 16$ and Treponema pallidum haemagglutination test (TPHA) (Shield Diagnostic, UK). Active syphilis was diagnosed when both tests were positive. Serum was also screened for antibodies to herpes simplex virus type 2 (HSV2) (Sorin srl, Italy). Antibodies to HIV1 and HIV2 were detected by synthetic peptide enzyme linked immunosorbent assay (ELISA, Behring Diagnostics, Germany). Serum was also screened for hepatitis B surface antigen (Bio-Kit, Barcelona, Spain), antibody to hepatitis core antigen, antibody to hepatitis $\mathrm{B}$ e antigen, hepatitis B e antibody, antibody to hepatitis D antigen, and antibody to hepatitis C (Diasorin srl, Vercelli, Italy). On the tests that 
were positive for anti-HCV (ELISA), a confirmatory line immunoassay was done (LIA, Diasorin, Italy).

For detection of bacterial vaginosis, specimens of vaginal exudate were collected with a swab from the posterior fornix of the vagina. The vaginal $\mathrm{pH}$ was tested using vaginal $\mathrm{pH}$ strips (Fishers, Atlanta, GA, USA). A whiff test was performed to detect amine odour, and the vaginal fluid was examined under the microscope to find clue cells. Bacterial vaginosis (BV) was defined according to the $\mathrm{Amsel}^{47}$ criteria-that is, the presence of any three of the following four symptoms: homogeneous white vaginal discharge, clue cells in a high power field $(\times 400)$ under microscope (wet mount), a vaginal $\mathrm{pH} \geqslant 4.5$, and the presence of amine odour. A second vaginal swab was taken for detection of bacterial vaginosis using Gram staining. The specimen was rolled on a glass slide which was then examined under oil immersion lens (1000x). A standardised 0-10 point scoring system (Nugent's criteria) was used to evaluate bacterial vaginosis on the basis of the presence of large Gram positive rods (lactobacilli), small Gram negative rods (gardnerella), and mobiluncus. A score equal to or more than 7 was considered positive for $B V{ }^{48}$

For trichomoniasis, a high vaginal specimen was examined under a microscope after adding normal saline solution for detection of motile trichomonads. A second high vaginal swab was inoculated into an In Pouch TV (Bio Med Diagnostics Inc, San Jose, CA, USA) for culture. Specimens for culture were kept at room temperature $\left(25-30^{\circ} \mathrm{C}\right)$ until delivered

Table 1 Background characteristics of women $(n=384)$

\begin{tabular}{|c|c|c|c|}
\hline Characteristics & No & $\%$ & Mean (SD) \\
\hline Age & & & $27.4(8.0)$ \\
\hline $15-20$ years old & 109 & $(28.4)$ & \\
\hline 21-29 years old & 105 & $(27.3)$ & \\
\hline $30-39$ years old & 125 & $(32.6)$ & \\
\hline $40-50$ years old & 45 & $(11.7)$ & \\
\hline \multicolumn{4}{|l|}{ Marital status } \\
\hline Currently married & 310 & $(80.7)$ & \\
\hline Never married & 14 & $(3.6)$ & \\
\hline Widowed & 17 & $(4.4)$ & \\
\hline Divorced & 4 & $(1.0)$ & \\
\hline Abandoned & 39 & $(10.2)$ & \\
\hline Number of children & & & $2.4(1.8)$ \\
\hline 0 children & 52 & $(13.5)$ & \\
\hline 1 child & 91 & $(23.7)$ & \\
\hline$\geqslant 2$ children & 241 & $(62.8)$ & \\
\hline \multicolumn{4}{|l|}{ Religion } \\
\hline Muslim & 381 & $(99.2)$ & \\
\hline Hindu & 4 & $(0.8)$ & \\
\hline \multicolumn{4}{|l|}{ Occupation } \\
\hline Not engaged in remunerated labour & 231 & $(60.2)$ & \\
\hline Engaged in remunerated labour & 148 & $(38.5)$ & \\
\hline Did not answer & 5 & $(1.3)$ & \\
\hline \multicolumn{4}{|l|}{ Highest grade completed } \\
\hline No schooling & 285 & $(74.2)$ & \\
\hline $1-3$ years & 41 & $(10.7)$ & \\
\hline $4-6$ years & 43 & $(11.2)$ & \\
\hline $8-12$ years & 12 & $(3.1)$ & \\
\hline Monthly family income in taka $(1000$ taka $=\$ 23)$ & & & $2995(1684)$ \\
\hline $300-1900$ & 90 & 23.4 & \\
\hline $1901-2900$ & 100 & 26.0 & \\
\hline $2901-3800$ & 84 & 21.9 & \\
\hline $3801-10600$ & 110 & 28.6 & \\
\hline \multicolumn{4}{|l|}{ Primary partner is a truck driver or truck helper } \\
\hline No & 324 & $(89.1)$ & \\
\hline Yes & 52 & $(13.5)$ & \\
\hline Does not currently have a primary partner & 12 & $(3.1)$ & \\
\hline \multicolumn{4}{|l|}{ Lives with in-laws/parents/relatives } \\
\hline No & 304 & $(79.2)$ & \\
\hline Yes & 80 & $(20.8)$ & \\
\hline
\end{tabular}

(2-4 hours later on average) to the laboratory. In the laboratory, the In Pouch TVS were incubated at $37^{\circ} \mathrm{C}$ and were examined microscopically on alternate days for up to 7 days for detection of the presence of motile trichomonads.

In addition to specific genital tract infections diagnosed through laboratory tests, other syndromes were diagnosed clinically. Candida albicans infection (candidiasis) was defined as the presence of curd-like vaginal discharge and a history of genital itching. Cervicitis was defined as either the presence of endocervical mucopurulent pus or friable cervix. Vaginitis was defined as the presence of abnormal vaginal discharge. And pelvic inflammatory disease was diagnosed when subjects with lower abdomen pain had any of the following physical symptoms: fever with a temperature $\geqslant 38^{\circ} \mathrm{C}$, abnormal vaginal or cervical discharge, cervical motion tenderness. ${ }^{49}$

\section{Results}

GENERAL CHARACTERISTICS OF STUDY

POPULATION

All 384 subjects provided information on their background characteristics.

The mean age of subjects was 27.4 years (it should be noted that subjects sometimes gave different ages on the questionnaire and in their clinical examination, illustrating that frequently they did not really know their exact age; the questionnaire responses were used). Eighty one per cent of the women were currently married. Only 12 women (3.1\%) reported not having a primary partner currently (husband or boyfriend). For nearly 14\% of the women their primary partner was a truck driver or a truck helper (a young man who rides with the driver and assists him).

Seventy four per cent of the women had never attended school and $60 \%$ were not involved in any income generating work. The monthly family income ranged from 300 taka (US\$7.00) to 10600 taka (\$235.00); $51 \%$ of the subjects' families earned at least 3000 taka (\$69.00) per month. Most (79\%) did not live with family members outside their nuclear family and only $52(13.5 \%)$ did not have any children.

PREVALENCE OF HIV AND HEPATITIS B, C, AND D As HIV and the three hepatropic infections share the same routes of transmission, it is not unusual that rates of infection for them all, with the exception of ever exposure to the hepatitis $B$ virus, would be similarly low. Of the 384 subjects, none was infected with HIV. While nearly $50 \%$ had ever been exposed to the hepatitis B virus, only $3.6 \%$ (14) were currently infective with hepatitis B. Among these 14 women, four $(28.7 \%)$ were highly infective. Only $1.6 \%$ of the subjects were infected with hepatitis C ( 10 were ELISA positive but confirmatory LIA tests found only six to be positive and two indeterminate) (table 2).

None of the subjects were infected with hepatitis D, a viral infection that typically results in clinically aggressive chronic liver disease. 
Table 2 Biological markers of HIV and hepatitis in women (diagnosed through serological tests)

\begin{tabular}{lcc}
\hline Serological marker & No & Positive (\%) \\
\hline HIV (ELISA) & 384 & $0(0 \%)$ \\
Hepatitis B (HBV) & & \\
$\quad$ Surface antigen (HBsAg) & 384 & $14(3.6)$ \\
$\quad$ Core antibody (anti-HBc) & 381 & $188(49.3)$ \\
$\quad$ Epsilon (e) antigen (HBeAg) & 14 & $4(28.7)$ \\
$\quad$ Epsilon (e) antibody (anti-Be) & 14 & $8(57.1)$ \\
Hepatitis D (HDV) & 14 & 0 \\
$\quad$ Antigen (HDAg) & 14 & 0 \\
$\quad$ Antibody (anti-HD) & 382 & $6(1.6)$ \\
Hepatitis C (HCV) & \\
$\quad$ Antibody (anti-HC) & &
\end{tabular}

${ }^{\star}$ Missing because of insufficient serum for serological tests.

PREVALENCE OF CLASSIC SEXUALLY TRANSMITTED DISEASES

Among STD, herpes simplex 2, trichomoniasis, syphilis, and gonorrhoea were prevalent in this population while chlamydia was not (table 3 ).

Co-infection with more than one STD was rare in this population. Two women were positive for both syphilis (RPR and TPHA positive) and trichomoniasis (culture on the subsample of 261 women), and two for both syphilis and gonorrhoea (PCR on urine). No woman was infected with both chlamydia and gonorrhoea (PCR on urine or endocervical swabs). Of the 123 subjects who tested positive for HSV2, 12 also tested positive for syphilis, six for gonorrhoea, four for chlamydia, and 16 for trichomoniasis.

PREVALENCE OF OTHER GENITAL TRACT

INFECTIONS

The prevalence of any genital tract infection caused by a non-STD (bacterial vaginosis, candidiasis) was $42 \%$.

Bacterial vaginosis was highly prevalent (37\%) and clinically diagnosed PID was identified among $5.7 \%$ of the study participants (table 4).

\section{Discussion}

HIV was clearly not a problem in this population as not a single case of infection was found.

Table 3 Prevalence of STD in women

\begin{tabular}{lcccl}
\hline Disease & $N{ }^{*}$ & Positive & $\%$ & Diagnostic test or examination \\
\hline Chlamydia & 384 & 0 & 0 & PCR on urine \\
Chlamydia & 261 & 09 & 3.4 & PCR on swab \\
Gonorrhoea & 384 & 24 & 6.3 & PCR on urine \\
Gonorrhoea & 261 & 14 & 5.4 & PCR on swab \\
Gonorrhoea & 247 & 32 & 13.0 & Gram stain \\
Syphilis & 384 & 22 & 5.7 & RPR and TPHA \\
Herpes simplex 2 & 384 & 123 & 32.0 & ELISA \\
Trichomoniasis & 261 & 21 & 8.0 & Wet mount \\
Trichomoniasis & 261 & 49 & 18.8 & Culture (In pouch TV) \\
Trichomoniasis & 261 & 51 & 19.5 & Culture or wet mount \\
\end{tabular}

* The sample size is 384 for tests requiring urine or blood samples. It is 261 for tests requiring a physical examination (and for some diseases cervical or vaginal specimens) as 99 subjects did not consent to the exam and another 24 subjects were pregnant. For Gram stains for gonorrhoea the sample size is only 247 because of the absence of a laboratory technician at times when subjects came to the clinic.

Table 4 Prevalence of genital tract infections in women

\begin{tabular}{lcccl}
\hline Disease & No & Positive & $\%$ & Diagnostic test or examination \\
\hline Bacterial vaginosis & 261 & 59 & 22.6 & Wet mount \\
Bacterial vaginosis & 261 & 97 & 37.2 & Gram stain \\
Candidiasis & 261 & 261 & 10.0 & Pelvic examination \\
Vaginitis & 261 & 108 & 41.4 & Pelvic examination \\
Cervicitis & 261 & 44 & 16.9 & Pelvic examination \\
PID & 261 & 15 & 5.7 & Clinical examination \\
\hline
\end{tabular}

Ever exposure to hepatitis B virus (49.3\%), on the other hand, was endemic. The prevalence rate of current infectivity (HBsAg), 3.6\%, was similar to the results obtained in other studies of females who are not CSW in Bangladesh; they have found rates of $0.8 \%,{ }^{9} 3.5 \%,{ }^{7}$ and $5.9 \% .^{5}$ Among CSW a rate of $9.7 \%$ has been reported. ${ }^{6}$ The level of HCV infection in our study was $1.6 \%$ and of HDV was $0 \%$. No comparable information on $\mathrm{HCV}$ and HDV in Bangladeshi women has been published.

There was a high prevalence of HSV2 $(32 \%)$ and syphilis $(5.7 \%)$. The level of syphilis infection was very similar to the rate in a population based study of 984 urban women in a Dhaka slum $(5.4 \%)$ (Sabin K, personal communication, 2000). That study's case definition of VDRL and TPHA positive was comparable with our definition of both RPR and TPHA positive; however, there were no dilutions in their VDRL tests while in our study the RPR had a dilution of $1: 16$. As a consequence, we would probably find fewer syphilis cases because of our use of a more specific testing procedure, with fewer false positives. Studies of brothel based CSWs in Bangladesh have found rates of syphilis infection ranging in one brothel from $6.8 \%$ (positive on VDRL at a greater than $1: 8$ dilution $)^{2}$ to $45.7 \%$ and $52.5 \%$ in two other brothels (positive on both RPR and TPHA apparently without dilution). ${ }^{4}$ Among street based sex workers, rates of syphilis infection of $32.6 \%{ }^{3}$ and $52.6 \%{ }^{4}$ (in both studies RPR and TPHA positive) have been found. There are no comparable studies of HSV-2 in Bangladeshi women who are not CSWs. A study of street based female sex workers reported that $62.5 \%$ were positive for HSV-2. ${ }^{3}$

PCR analysis on urine samples detected that $6.3 \%$ of our subjects were infected with gonorrhoea and none was infected with chlamydia. The latter findings differed somewhat when PCR analysis was conducted on swabs for the subsample of 261 women who were physically examined and provided endocervical specimens. The prevalence of chlamydia in PCR analysis on swabs was $3.4 \%$ and of gonorrhoea was $5.4 \%$. Trichomoniasis was detected in $19.5 \%$ of the 261 women.

These rates of infection were higher than those detected in the study of 984 urban women living in slums in Dhaka which reported infection rates of $<1 \%$ for chlamydia, $1.8 \%$ for gonorrhoea (PCR on urine), and $2.6 \%$ for trichomoniasis (culture with self administered swabs) (Sabin K, personal communication, 2000). And rates of infection in our study group were much higher than in a clinic based study of rural women (with sample sizes varying from 395 to 463 depending on the disease) where the prevalence of disease was very low: $0.2 \%$ had gonorrhoea and $0.9 \%$ chlamydia (PCR on urine), $1.5 \%$ trichomoniasis (wet mount), $18.9 \%$ bacterial vaginosis (Gram stain), and $12.6 \%$ candidiasis (wet mount). ${ }^{1}$ The prevalence in our study sample was lower, on the other hand, than in sex workers who have been reported to have gonorrhoea infection rates of $35.6 \%$ (culture) $^{3}$ and $19.9 \%$ (PCR on endocervical swab) $^{2}$ and chlamydia 
rates of $18.2 \%$ (PCR on endocervical swab) ${ }^{2}$ and $25 \%$ (PCR on endocervical swab). ${ }^{3}$

The findings of this study suggest that women living adjacent to Tejgaon truck stand are at intermediate levels of risk for STD and genital tract infections. Given the very low levels of condom use in Bangladesh, ${ }^{50}{ }^{51}$ even in the context of high risk sexual relations (a study of $300 \mathrm{CSWs}$ found that only $11.8 \%$ had ever used a condom ${ }^{52}$ ), it is unlikely that efforts to promote condom use to women for sexual relations with their primary partner would be successful. However, in the context of more casual relations it might be possible (one study of male condom users in Bangladesh found that they were used more in relations outside marriage than within marriage ${ }^{53}$ ). Targeting men's behaviour and encouraging the use of condoms in casual relations, particularly with commercial sex workers, is essential both because of men's role in sexual decision making as well as the fact that it is their sexual behaviour outside their primary union ${ }^{54-56}$ that frequently puts their wives at risk for infection. In a study of truck drivers and helpers at Tejgaon truck stand, $50 \%$ of the 180 married men in the sample reported having sex both a CSW and their wife in the past year. Further, of the 211 truck drivers and helpers who had had sex with a CSW in the past year, $64 \%$ had never used a condom in their life and 9\% had only used one once (Gibney L, unpublished data, 2000). This low level of use occurs in a context in which condoms are widely available in Dhaka (shops and pharmacies sell them, government field workers distribute them), and in which AIDS awareness and condom promotion is occurring in some brothels.

With respect to other risk factors for HIV and hepatitis, injection drug use appears to be at a very low level in Bangladesh and, thus, not to be an important risk factor currently. ${ }^{57}$ There are some data, however, to suggest that therapeutic practices such as unsterile injections $^{58}$ (Gibney L, unpublished data, 2000) and blood transfusions with tainted blood ${ }^{59} 60$ may be risk factors. Further study of the risks posed by transfusion and injection practices is needed before any conclusion can be drawn.

We are very grateful to the World AIDS Foundation which was the primary funder of this study (principal investigator Dr Laura Gibney). We are also appreciative of the additional financial contributions in the formative phase of the project from the John J Sparkman Center of the University of Alabama at Birmingham (director, Dr Jose Alvarez) and the UAB AIDS International Training and Research Program, Fogarty International Center (PI Dr Sten Vermund). And, finally, we are grateful to the personnel from UAB and Paricharia for their assistance with the study, to the staff of BIRDEM's immunology laboratory for study, to the staff of BIRDEM's immunology laboratory for men in the trucking industry who graciously volunteered to men in the trucking in
participate in this study.

Contributors: LG is the study principal investigator responsible for all aspects of the study; $M M$ is a co-investigator who for all aspects of the study; $M M$ is a co-investigator who
contributed to the study research design and write up; KK is a contributed to the study research design and write up; KK is a co-investigator who contributed to the research design and write
up; MSH is a co-investigator responsible for all laboratory up; $\mathrm{MSH}$ is a co-investigator responsible for all laboratory analyses; JS is a co-investigator who contributed to the research design and to the determination of clinical and laboratory protocols; SV is a co-investigator who contributed to the research
design; PC is a co-investigator who contributed to the project's design; PC is a co-investigator who contribute

1 Hawkes S, Morison L, Foster S, et al. Reproductive tract infections in women in low-income, low-prevalence situBangladesh. Lancet 1999;354:1776-81.
2 Sarkar S, Islam N, Durandin F, et al. Low HIV and high STD among commercial sex workers in a brothel in Bangladesh; scope for prevention of larger epidemic. Int $\mathcal{F}$ STD AIDS 1998:9:45-7.

3 Rahman M, Alam A, Nessa K, et al. Etiology of sexually transmitted infections among street-based female sex workers in Dhaka, Bangladesh. $\mathcal{F}$ Clin Microbiol 2000;38: 1244-6.

4 Azim T, Islam MN, Bogaerts J, et al. Prevalence of HIV and syphilis among high-risk groups in Bangladesh. AIDS 2000;14:210-11.

5 Rahman MA, Sattar H, Rahman $M$, et al. Seroepidemiological study of hepatitis B virus infection in a vil-
lage. Bangladesh Med Res Council Bull 1997;23:38-41.

6 Sattar H, Islam MN. Hepatitis B virus markers among the prostitutes of Dhaka. Bangladesh Med Res Counc Bull 1996; 22:8-11.

7 Rumi MA, Begum K, Hassan MS, et al. Detection of hepatitis B surface antigen in pregnant women attending a public hospital for delivery: implications for vaccination strategy in Bangladesh. Am f Trop Med Hyg 1998;59:318-

8 Ahmad Q, Chowdhury SG, Islam $\mathrm{MN}$, et al. HBsAg mongst unscreened operated patients. Bangladesh Med Res Council Bull 1991;17:11-16.

9 Laskar MS, Harada N, Khan F. Prevalence of hepatitis B surface antigen (HbsAg) in Viqarunnessa noon girls' school children in Dhaka, Bangladesh. Cent Eur $\mathcal{F}$ Public Health 1997;5:202-4.

10 Khan M, Husain M, Yano M, et al. Comparison of seroepidemiology of hepatitis $\mathrm{C}$ in blood donors between Bangladesh and Japan. Gastroenterol fap 1993;28(Suppl 5):2831 .

11 Zaman S, Khan M, Alam K, et al. Primary hepatocellular carcinoma and viral hepatitis B and C infection in Bangladeshi subjects. F Trop Med Hyg 1995;98:64-8.

12 Bwayo JJ, Plummer F, Omari M, et al. Human immunodeficiency virus infection in long distance truck drivers in east Africa. Arch Intern Med 1994;154:1391-6.

13 Carswell JW, Lloyd G, Howells J. Prevalence of HIV-1 in East African lorry drivers. AIDS 1989;3:759-61.

14 Mohamed Ali, Bwayo JJ, Mutere AN, et al. Sexual behavior of long distance truck drivers and their contribution to the spread of sexually transmitted diseases and HIV infection in East Africa. International Conference on AIDS 1990 (abstract no FC729);6:263.

15 Mbugua GG, Muthami LN, Mutura CW, et al. Epidemiology of HIV infection among long distance truck drivers in Kenya. East Afr Med f 1995;72:515-18.

16 Podhisita C, Wawer JM, Pramualratana A, et al. Multiple sexual partners and condom use among long-distance truck drivers in Thailand. Aids Education and Prevention 1996;8:490-498.

17 Singh YN, Malaviya AN. Long distance truck drivers in India:HIV infection and their possible role in disseminating HIV into rural areas. Int $\mathcal{F}$ STD AIDS 1994;5:137-8.

18 Singh YN, Singh K, Joshi R, et al. HIV infection among long distance truck drivers in Delhi, India. $\mathcal{F}$ Acquir Immune Defic Syndr 1993;6:323.

19 Alam S, Biswajit R, Islam T. Population assessment on truckers on STD/HIV/AIDS. International Conference on truckers on STD/HIV/AIDS. International Con

20 Mahmud H, Kabir MA, Mian MA, et al. Behavioral risk assessment and serology for syphilis, hepatitis B and HIV among commercial sex workers in an isolated brothel in Goalanada, Rajbari. International Conference on AIDS 1998;12:642 (abstract no 33248).

21 Nzyuko S, Lurie P, McFarland W, et al. Adolescent sexual behavior along the Trans-Africa highway in Kenya. AIDS 1997;11(Supp1 1):S21-6.

22 Nyamuryekung'e K, Laukamm-Josten U, Vuylsteke B, et al. STD services for women at a truck stop in Tanzania: Evaluation of acceptable approaches. East Afr Med f 1997; 74:343-7.

23 Wild CP, Hall AJ. Primary prevention of hepatocellular carcinoma in developing countries. Mut Res 2000;462: 381-93.

24 Hadziyannis SJ, Giannoulis G. Hepatitis C virus infection in Greece and its role in chronic liver disease and hepatocelluar carcinoma. F Hepatol 1993:17 (suppl 3):572-7.

25 Zhang J-Y, Dai M, Wang X, et al. A case-control study of hepatitis $\mathrm{B}$ and $\mathrm{C}$ virus infection as risk factors for hepatocellular carcinoma in Hunan, China. Int f Epidemiol 1998; 27:574-8.

26 De Cock KM, Govindarajan S, Valinluck B, et al. Hepatitis $\mathrm{B}$ virus DNA in fulminant hepatitis B. Ann Intern Med 1986;105:546-7.

27 De Cock KM, Govindarajan S, Chin KP, et al. Delta hepatitis in the Los Angeles area:a report of 126 cases. Ann Intern Med 1986;105:108.

28 Alter HJ, Purcell RH, Shih JW, et al. Detection of antibody to hepatitis $\mathrm{C}$ virus in prospectively followed transfusion recipients with acute and chronic non-A, non-B hepatitis. N Engl F Med 1989;321:1494-500.

29 Lamden KH, Kennedy N, Beeching NJ, et al. Hepatitis B and hepatitis $\mathrm{C}$ virus infections:risk factors among drug users in northwest England. F Infect 1998;37:260-9.

30 Szmuness W, Much I, Prince AM, et al. On the role of sexual behavior in the spread of hepatitis B infection. Ann Intern Med 1975;83:489-95.

31 Alter MJ, Ahtone J, Weisfuse I, et al. Hepatitis B virus transmission between heterosexuals. $\mathcal{F} A M A$ 1986;256:1307. 
32 Rosenblum L, Darrow W, Witte J, et al. Sexual practices in the transmission of hepatitis $\mathrm{B}$ virus and prevalence of the transmission of hepatitis $\mathrm{B}$ virus and prevalence of hepatitis delta virus infection in female pro

33 Wu JC, Lin HC, Jeng FS, et al. Prevalence, infectivity, and risk factor analysis of hepatitis C virus infection in prostitutes. F Med Virol 1993;39:312-7.

34 Davis LG, Weber DJ, Lemon SM. Horizontal transmission of hepatitis B virus. Lancet 1989;1:889-93.

35 Stevens CE, Toy PT, Tong MJ, et al. Perinatal hepatitis B virus transmission in the United States: prevention by passive active immunization. $\mathcal{F} A M A$ 1985;253:1740-5.

36 Cotch MF, Pastorek JG 2nd, Nugent RP, et al. Trichomoniasis vaginalis associated with low birth weight and preterm delivery. The Vaginal Infections and Prematurity Study Group. Sex Transm Dis 1997;24:353-60.

37 Goldenberg RL, Thom L, Moawad AH, et al. The pre-term prediction study: fetal fibronectin, bacterial vaginosis and prediction study: fetal fibronectin, bacterial vaginosis and Unit Network. Obstet Gynecol 1996;87:656-60.

38 Newton ER, Piper J, Pearis W. Bacterial vaginosis and intraamniotic infection. Am f Obstet Gynecol 1997;176: intraam $672-7$.

39 Westrom L. Effect of pelvic inflammatory disease on fertility. Am f Obstet Gynecol 1975;121:707-13.

40 Holmes KK, Eschenbach DA, Knapp JS. Salpingitis: overview of etiology and epidemiology. Am $\mathcal{F}$ Obstet Gynecol 1980;138:893-900

41 Brunham RC, Binns B, Guijon F, et al. Etiology and outcome of acute pelvic inflammatory disease. F Infect $D i$ 1988;158:510-7.

42 Cates W, Rolfs RT, Aral SO. Sexually transmitted diseases, pelvic inflammatory disease and infertility: an epidemiologic update. Epidemiol Rev 1990;12:199-220.

43 World Health Organization Task Force on the Prevention and Management of Infertility. Tubal infertility: serologic relationship to past chlamydial and gonococcal infection. Sex Transm Dis 1995;22:71-7.

44 Wasserheit JN. Epidemiological synergy. Interrelationships Wasserheit JN. Epidemiological synergy. Interrelationships between human immunodeficiency virus infection and other sexually

45 Laga M, Nzila N, Goeman J. The interrelationship of sexually transmitted diseases and HIV infection: implications for the control of both epidemic in Africa. AIDS 1991;5(Suppl 1):S55-63.

46 Cohen CR, Duerr A, Pruithithada N, et al. Bacterial vaginosis and HIV seroprevalence among female commercial sex workers in Chiang Mai, Thailand. AIDS 1995;9:1093-7.
47 Amsel R, Totten PA, Spiegel CS, et al. Non-specific vaginitis: ditnostic and microbial and epidemiological vaginitis: diagnostic and microbial and

48 Nugent RP, Krohn MA, Hillier SL. Reliability of diagnosing bacterial vaginosis is improved by a standardized method of gram stain interpretation. F Clin Microbiol 1993;29:297301 .

49 Family planning, STD, RTI and HIV/AIDS Task Force of QIP of NIPHP, Bangladesh. Technical standard and service delivery protocol for management of RTIs and STDs. November 1997.

50 Mitra SN, Ali N, Islam S, et al. Bangladesh Demographic and Health Survey, 1993-1994. Calverton, Maryland: National Institute of Population Research and Training, Mitra and Associates, Macro International, 1994.

51 National AIDS Committee. KABP Survey in Relation to AIDS in Bangladesh. Dhaka: NAC, 1990.

52 Sarkar S, Durandin F, Jana S, et al. A community-based survey of commercial sex workers (CSWs) in a brothel of Bangladesh on knowledge, intent trial, and practice for use of condom. Ascon VI. Sixth Annual Scientific Conference, Programme and Abstracts. Dhaka, Bangladesh, March 1997.

53 Folmar S, Alam SMN, Raihan S. Condom use in Bangladesh:final report. Family Health Int 1992.

54 Caldwell B, Pieris I, Barkat-e-Khuda, et al. Sexual regimes and sexual networking:the risk of an HIV/AIDS epidemic in Bangladesh. Soc Sci Med 1999;48:1103-16.

55 Aziz KMA, Maloney C. Life stages, gender and fertility in bangladesh. Dhaka, Bangladesh: International Centre for Diarrhoeal Disease Research, Bangladesh, 1985. Monograph no 3.

56 Haider SJ, Saleh SN, Kamal N, et al. Study of adolescents: dynamics of perception, attitude, knowledge and use of reproductive health care. Dhaka, Bangladesh:Population Council, 1997.

57 Begum A. Drug dependence problems in DhakaBangladesh. Bangladesh Med f 1991;20:33-9

58 Ahmad Q, Chowdhury SG, Islam MN, et al. HBsAg amongst unscreened operated patients. Bangladesh Med Res Council Bull 1991;17:11-6.

59 Khan M, Husain M, Yano M, et al. Comparison of seroepidemiology of hepatitis $\mathrm{C}$ in blood donors between Bangladesh and Japan. Gastroenterol fap 1993;28(Suppl 5):2831

60 Hossain S, Bhuiya I, Streatfield K. Professional blood donors, blood banks and risk of STD and HIVIAIDS: a study in selected areas in Bangladesh. Dhaka, Bangladesh: Population Council, 1996, Regional Working Paper no 6. 